\title{
Methodological Background and Foundations of the Non-Material Theory of the Psyche
}

\author{
Professor Mikhail Reshetnikov, MD, PhD \\ Meritorious Scientist of the Russian Federation, \\ East European Psychoanalytic Institute, Rector, \\ St. Petersburg State University, Member of the Scientific Board \\ Honorary Professor of the Sigmund Freud University, Vienna, Austria
}

\begin{abstract}
SUMMARY
In this paper, a number of outdated but still prevailing medical doctrines are critically reviewed, in particular, Hippocrates's hypothesis of the brain as a repository of all mental processes; I.M. Sechenov's hypothesis of the psyche as a derivate of the brain reflexes; I.P. Pavlov's hypothesis of the higher nervous activity as an equivalent of the psyche. In his research, the author refers to studies of feral children, studies of memory and subliminal perception, discovery of mirror neurons and contemporary views of the academic science on information. The author proves the non-materiality of the psyche and the role of the brain as a biological interface between the ideal and the real. The new approach would require changing the traditional paradigm as well as all our approaches to studying the psyche and treating mental disorders.
\end{abstract}

Key words: biological interface, brain, mind, non-material theory, psyche, psychic disorders.

We can't solve problems by using the same kind of thinking we used when we created them.

Albert Einstein

\section{INTRODUCTION. IDEAS LIVE THEIR OWN LIFE}

The geocentric system by Claudius Ptolemy, according to which the Earth is the centre of the Universe, and all other stars and planets are revolving around it, was born in II A.D. and persisted for 15 centuries. In 1530, Nicolas Copernic developed the heliocentric system, in which the centre of the solar system is the Sun. This idea, however, had been suggested much earlier, in IV-III BC, by Aristarchus of Samos. In result, he was accused of impiety and exiled from Athens. The revolutionary discovery made by Copernicus stirred the same reaction, as his system was perceived as undermining the authority of the Church, which controlled the science in that epoch. His premature death saved Copernicus from a severe punishment. However, adepts of his theory were persecuted for a long time afterwards. In 1600, the inquisition sentenced Giordano Bruno, a monk and a scholar, to death by burning for disseminating Copernicus's ideas.

This historical excurse shows that ideas have their own life: they are born, develop, get older and die, sometimes agonizing in tormenting pain and clinging for life, while still persisting in minds of their powerful adherents, figures of authority. Agonizing ideas still have power though and can be murderous. They are able to kill not only other ideas but also people. In contrast to such areas as astronomy, genetics or psychoanalysis, where only a few prominent scientists were persecuted or ostracized for their innovations, in medicine, ideas can be 
murderous not only for researchers but also for thousands of innocent patients. This topic will be discussed in detail below.

\section{Theory-ladenness}

In contemporary science, theory-ladenness is understood as adherence to outdated ideas, which can influence not only interpretations of facts but also design of new experiments, so that the latter are initially constructed in accordance with an outdated theory. Such experiments are doomed to confirm the established misconceptions, result in elaboration of sophisticated theoretical schemata and are abundantly financed but fruitless.

In our informational epoch, problems of the psyche have become crucial for all aspects of social life, and raising and solving them will directly influence development of philosophy, sociology, political studies, somatic medicine, psychiatry, psychology, solutions of the problem of informational explosion, subjects of advanced technologies, brainwashing systems, artificial intelligence etc.

\section{Substitution of notions}

For the last two thousand years, the psyche has been understood, in the most primitive terms, in accordance with the hypothesis suggested by Hippocrates, who declared that the brain is a repository of all mental processes. Outstanding adherents of this hypothesis, such scholars as R. Descartes (1), I.M. Sechenov (2), I.P.Pavlov (3), determined the main directions in further development of physiology, psychology and psychiatry, and there are many less known specialists who followed them. Mistakes made by great people are great mistakes, and we will return to this topic later.

Due to authoritative support from these genial scholars, Hippocrates's hypothesis gradually became the prevailing scientific doctrine, which was further elaborated with development of science and invention of more sophisticated research equipment. The psyche was being looked for in cortex, gyros, ventricles of the brain, the subcortical brain, conditional reflexes, electric activity, wave activity and quantum activity of the brain. And finally - what a miracle! - it has been found in the synaptic cleft (4), and the exchange of neurotransmitters was implicitly recognized as an equivalent of the psyche and the target of contemporary psychopharmacology.

Surprisingly, for two thousand years, scientists have not noticed this substitution of notions: they were speaking about studying and treating the psyche, but in reality, they were studying and treating the brain and elaborating pseudo-physiological and pseudo-psychological terminology to describe "the brain mechanisms of mental processes".

Let us try to explain this fallacy in rather simple terms. It can be compared to identifying the computer with its hardware (while its software can be totally neglected) and trying to measure physical characteristics of the hardware, such as voltage and resistance at the terminals of its power grid, in order to conclude something about the software, e.g., which operating system is installed.

Any sensible individual can understand that it is an absurd. However, similarly nonsensical attempts to decipher human thoughts by means of EEG were practiced in dozens of scientific centres; later they were replaced by "reading thoughts" via computer neuro-visualization. The scientific centres working on such ideas remind me of a curious historical example. In the USSR, there was a special research program conducted for a few decades by the Scientific Research Institute of the Brain at the USSR Academy of Science. Its goal was to study anatomy 
of Lenin's brain in order to find material (histological) explanations of his brilliancy. Of course, the author does not deny significant findings made by Soviet scientists at the same time as they were pursuing this hopeless line of research based on the most primitive materialism. However, we are not far from this fallacy ourselves, when we focus our scientific interests on the synaptic cleft and looking for the psyche in it.

\section{Fallacies in medicine}

There are mistaken ideas and theories in all sciences. However, in medicine, the mistaken ideas about the psyche are in some respects different from ideas in other sciences. Hypotheses of the psyche, as soon as there were formulated, would instantly give birth to theories of psychopathology, which were immediately introduced, without critical review, into the practice of therapy and even surgery related to mental disorders. Millions of people have become subjects of these experiments. The anatomic approach to "structures of the psyche" resulted in lobotomy and dissection of callosum; the idea of electric activity of the brain led to thousands of "therapeutic" experiments with the ECT; after that, the insulin shock was suggested but was later considered doubtful; and historically newest biochemical theories of the psyche gave birth to psychopharmacology as a new branch of chemical industry. Currently, therapy of mental disorders is conducted mostly by means of psychopharmacology, which targets the exchange of neurotransmitters in the synaptic cleft and thus is supposed to influence the psyche. The question is still unresolved, whether these newest methods of therapy are really effective for treating patient from mental disorders.

What is in common in all these outstanding scientists, from Hippocrates to our contemporaries? They all were attracted by a powerful and very seductive - and extremely materialist - idea: to find a material substrate of the psyche. It is important that what they meant was not a material structure, on which the psyche is based, but a material substrate of the psyche as such. This is an utterly fallacious idea.

Qualitatively different approaches to the psyche have been suggested very seldomly. Only a few names can be mentioned, such as S. Freud, who considered the psyche an epiphenomenon (5) and V.M. Bekhterev, who stated that psychiatry is a science of spirit and thus can hardly be considered a part of scientific medicine (6). Works of D.I. Dubrovsky should not be underestimated as well; in 1960-s he published a number of philosophical works on the informational approach to the subjective reality (7).

\section{The hypothesis of the biological interface}

In opposition to these traditional views on the psyche - and in line with such outstanding scholars as I.P. Pavlov, who developed the notion of the second signal system - the author of the current paper suggested a hypothesis of the brain as the biological interface in $2008(8,9)$. This hypothesis elaborated the abovementioned parallel between the brain and the computer. The brain was compared to the computer hardware, and the psyche to the software. Education of the child, who was learning to use a language to communicate, was considered a kind of programming. Let us stress that the programming in technical systems also requires a certain language.

Mental activity is viewed as a kind of informational exchange and interaction, as well as accumulation and processing of information, which is possible only when a child from the earliest stages of life is immersed into a social (informational) environment functioning as an equivalent of the global net. Let me remind you J. Lacan's saying (10) that the child is born into "the baptismal font of the language", or, in contemporary terms, his psyche is connected to the 
informational network of the society (it has been shown by contemporary science that it happens as early as at the pre-natal stage).

One of the key postulates of the hypothesis suggested in 2008 was the following: with time, the special role of the brain will be reconsidered, and in a new framework it will acquire a rather modest but also important role of the link between the ideal and the real, or, in contemporary terms, of the biological interface (8).

Nobody would deny that the brain and the nervous system are material structures regulating activities of internal organs, reflex reactions and adaptive functions of the organism, and mental activity is based on these structures.

But the essence of mental activity is different. We accumulate information, process and verify information, produce information. It is the content of mental processes, which can be studied only by means of self-observation or recognized via indirect manifestations in speech and ideomotor reactions. However, we should not forget that thought and speech follow different laws. It should be admitted that what we think differs from what we say too often, not only in the everyday life but also in scientific generalizations.

\section{THE NON-MATERIAL THEORY OF THE PSYCHE}

Further development of the suggested hypothesis $(11,12-16)$ was related to a very important concept, which had been neglected by psychologists, physiologists and psychiatrists for a long time and was not included into their theories and hypotheses. Information is understood by contemporary academic science as a non-material factor. Let me remind you that the founder of cybernetics N. Wiener emphasized that information is neither matter nor energy, information is information (17). Later this concept became universally accepted in academic science. Only information carriers (biological, paper, electronic etc.) are material. It should be admitted that the definition given by N. Wiener is not the best one. It would be much more precise to say that information is a structure that belongs to categories of the ideal (we will return to this term later).

Although information is non-material, it acquires (but does not have initially!) certain qualitative and quantitative characteristics. It can be neutral, emotionally charged, threatening, true, false etc., but all these characteristics are acquired only in presence of a subject of its perception; in different subjects, the same information can stir completely different mental reactions (let us remember September 11, 2001, mourning in the USA and joyful crowds in Livia).

Information as such, on a carrier but without a perceiving subject, is virtually non-existent. Only living beings, and most of all, humans can be subjects of its perception, as well as produce, carry, store and verify non-material information.

\section{Fallacies that distort the scientific truth}

The prevailing idea of the brain as a repository of all psychic functions gave birth to a number of fallacies, which pervade our speech in the everyday life and led to the scientific phenomenon of theory-ladenness, when everything incompatible with the prevailing scientific doctrine is rejected. There are common phrases, such as "it is getting on my nerves", although nerves are just conductors, or "it has stuck in my head", although it is about mind, not head, etc. Generally speaking, there is a pervasive identification of the nervous and the psychic at the level of laymen and even at the level of scientific knowledge. When I am reading works of contemporary scientists - physiologists, psychologists, psychiatrists - I am amazed to see such 
phrases as "the brain recognized", "the brain commanded", "the brain analysed" etc. Generally speaking, the phrase "we think with the brain" is as absurd as the phrase "we walk with the spinal cord" just because it relates to motility impulses.

Let us turn once again to the abovementioned metaphorical explanation: it is not the computer that remembers something, finds it, calculates or analyses it. It is done by the non-material software, without which a computer is just a piece of metal. Similarly, the brain without the psyche which was formed under the influence of a society is just a biological substrate, a tissue that includes synapses, chemical mediators, nervous centres, transmitters, etc., but nothing more than that.

Contemporary human sciences are neglecting the crucial differences between the nervous system and the psyche. There are a few of them, but the main one is the following: the healthy psyche is able to differentiate imaginary stimuli from real ones. The nervous system reacts to them both in almost the same way. This is the basis of all techniques of suggestion and selfsuggestion; for instance, when one imagines that his hand immerses into hot water, the skin temperature of his palm raises, or when one imagines sprinting 100 meters, his pulse increases.

We can also remember classical experiments by J. Charcot: when a patient, a woman with no medical knowledge, was hypnotised, she felt that her hand was paralyzed not in innervation zones, as in case of real paralyses, but "as a whole", as it was represented in the patient's mind. It is strange that neither J. Charcot himself, nor S. Freud and V.M. Behkterev, who observed his experiments, managed to make a rather reasonable conclusion: it is not the nervous system which rules the psyche but the psyche controls the nervous system, at least in this specific case.

\section{The brain is also soma}

Ideas of a possible influence of the psyche on somatic functions, which were formulated by J. Heinroth in 1818, were revolutionary and contradicted the notions of "psychic structures of the brain", therefore they were for more than 100 years rejected by official science and held mostly by laymen (18). When aetiology of a patient's disease was puzzling for doctors, the patient himself or his relatives would easily recognize that he was "struck by grief" or "heartbroken by his love". Gradual recognition of the concept of psychosomatic pathology should have refuted the established identification of psychic phenomenon and their material carriers in medicine, such as the brain and its physiological and biochemical processes. However, this discovery stayed for the long time unnoticed by the psychiatry and the medicine in general.

In 1930-s it was finally recognized that the psyche influences soma; psychosomatic societies of medical doctors and psychosomatic departments in hospitals were established. In the world outside specialized psychosomatic clinics, however, the two-thousand-year-old approaches to therapy of mental and psychosomatic disorders persisted. This therapy still consists of treatment of a single organ and psychopharmacological influence on somatic structures of the brain. It implies that the psyche is still understood as a set of chemical reactions or a derivate of the brain structures, like bile is the derivate of the liver.

\section{Psychopathology and psychopharmacology}

Let us turn to psychopathology now. It seems that two different types of psychopathology, which requires two different treatment approaches, have not been clearly differentiated yet. These are: 
1. psychopathology resulting from organic damage of the brain, such as infectious processes, sclerotic change, oncological disease, etc. In such cases, the brain as an information carrier is damaged; in analogy with the computer, its hardware is damaged. In these cases, it is easy to locate the damaged part of the brain by external manifestations of the disorder (sensory, motor, behavioural and psychic reactions), and approaches of biological medicine are appropriate: the brain should be treated by chemicals, or surgery, or rays, or lasers, etc.

2. psychopathology that develops because of an informational damage to the psyche itself, that is, a non-material factor (for instance, an individually important psychic trauma) has damaged another non-material factor (a normally functioning psyche), similarly to a computer virus (information) damaging a normally functioning software.

Let us illustrate the second version with a simple example. In October 2005, when the war in Chechnya was already over, there was news on the Internet that students in a Chechen school were affected by a nervous poison. First, one girl was declared to be a victim, then two, then three more, and then 29 students. After the news was broadcasted on TV, the same situation happened in a few more schools, which were situated in dozen kilometres from the first one. When this "poisoning" (which led to hospitalization, in October-December 2005, of 86 children!) was studied more thoroughly, it appeared to be a case of massive psychic "infection" by false ideas, what is currently called "an informationally contracted disease". The same paranoid scenario is typical for inter-ethnic conflicts.

In contrast to the first type of pathology described above, mental disorders of this second type can take very different forms that depend on individual characteristics of the subject: from slight dysphoria to severe depression, autism or persistent paranoia (in combination with psychosomatic disorders). Therapy in such cases should consist of informational influence on damaged structures, which are psychic rather than brain structures.

Chemical influence on the brain tissues, which can be compared to the computer hardware, will be ineffective in this case; psychic contents will stay unchanged. It is similar to attempts to get rid of a computer virus by pouring an acid or alkaline onto its electric terminals (its "synapses").

There are a few detailed and valid classifications of psychopharmacological medications, but they can be also roughly divided into two main groups:

1. Substances which dull mental experiences (in context of our metaphor, they decrease brightness of the interface, or a screen, to which information is projected); this group includes all neuroleptics, tranquilizers and anti-depressive medications;

2. Substances, which, on the contrary, stimulate mental activity and intensity of perception (increasing energy supply to all processes in the brain), in particular, nootropics and psychostimulants.

However, neither the first nor the second group can change the content of the psyche (information itself). It does not mean any negative attitude to psychopharmacology, as its success cannot be denied. The author is not against psychopharmacology but against its groundless prescription and long, isolated and uncontrollable use.

It is undeniable that a psychotic patient who is hospitalized with delusions, hallucinations or aggression should be treated urgently, because the longer is the acute phase, the more sever, with each such episode, is his emotional-volitional and intellectual deficiency. However, the urgent treatment should not last for months and years, considering the fact that medical science has not registered cases when severe 
psychopathology was completely overcome. It should be mentioned that an outstanding French scientist H. Laborit (19), one of the specialists who invented chlorpromazine (the first neuroleptic recommended to use against schizophrenia in 1952) in his late years made an unexpected confession that this invention was nothing more than "a chemical straightjacket" (8:55). It is difficult to disagree with it.

In other cases of mental disorders, when there is no need for a straightjacket (and no indications of an organic pathology of the brain), the main task of psychiatrists, psychotherapists and psychologists is to study psychogenesis of the patients' suffering and influence their psychic contents rather than the brain.

What is also important, in contrast to artificial intelligence with its predetermined parameters, expected results of analysis and synthesis and prognosed vectors, human intelligence is highly capable of self-development, unpredictable and subjective in its perception of information, with non-standard and widely varying decisions (8). The other difference is that information, which damages normally functioning psyche (an acute or chronic psychic trauma) can comes from outside (like a computer virus) or be created by the psyche itself, as false ideas, feelings of suspicion etc., which become self-traumatizing factors.

\section{ADDITIONAL ARGUMENTS}

A number of additional arguments supporting the abovementioned theory can be discussed. Studies of feral children (who are more known as Mowgli) show that normal human psyche cannot develop without early immersion into social environment (or, as it has been mentioned above, without language programming of the child's brain by social environment) (20). As we know, a personality develops when is "acquires its own bodily being that differs from bodily being of an individual" (21). Therefore, such individuals are called feral from Latin "feralis", which means "dead" or "buried alive" (in social sense), in this case buried in his own body, because these individuals belong to hominid family and genus of homo, but do not belong to Homo sapience.

However, such children learn certain forms of communication ("language") typical for an animal community, in which they survived. It leads to conclusion that the healthy brain is a necessary but not sufficient condition of development and adequate functioning of the human psyche; immersion into social environment and language programming of the psyche are also vitally important.

Well known cases of feral children who could communicate only in language of wolves or dogs, or were whistling like birds, have been described in scientific literature. It has been mentioned in these papers (22) that feral children, after long years in an animal community, would learn the behaviour of their "adopted parents", and all efforts of psychologists and rehabilitation specialists to change this behaviour were futile.

Prior to making one more conclusion, let us consider a recent case of this kind. In 1992, a seven-year-old girl was found in Ukraine, who had developed normally until her severely disturbed alcoholic parents made her live in a kennel with their dog. Quite soon, the girl stopped eating and drinking in a human way and started lapping her food; she lost her speaking skills almost completely and started barking and howling like a dog; although she had learnt to walk upright, she stopped doing it and started walk at all fours. Child protection agencies received information about this case too late; the girl was admitted to a special institution for children with developmental deficiencies. Medical doctors and psychologists who observed Oksana mentioned that she preferred to walk at all fours and jump from the 
floor to the table; when people approached her, she would show her teeth, roar and try to bite them. She could understand some primitive phrases but almost never talked herself. She would frequently take a flight from the institution in order to join a company of dogs, with whom she identified herself.

It allows us to formulate one more suggestion, that is, psychic structures and human culture are very fragile. From this perspective, contemporary tendency to be tolerant to various subcultures and indulgently accept what had previously been forbidden by the culture requires thoughtful and careful reconsideration.

\section{The second group of additional arguments}

A.R. Luria's The Small Book of the Large Memory (23) should be specifically mentioned here. The author described a mnemonist, a professional journalist S.V. Shershevsky, whom he observed for more than 30 years and whose pathology was related to his inability to forget anything. In his foreword to American edition of this book (1965), J. Bruner admires scientific foresight of the author and calls A.R. Luria "a time traveller from the future". There were some reasons for it. For instance, Luria proved that the psyche functions like a contemporary videorecorder (which did not exist at that time yet): it records everything a person sees and hears. The subtitle of the book is A Mnemonist's Mind. It has not drawn much attention, but I think that A.R. Luria emphasizes one of the main ideas of his book: he speaks not about the brain of the mnemonist but about his mind (the psyche).

S.V. Shershevsky could describe in detail what was in A.R. Luria's office and what was on his table during his first visit, which was decades ago. If Luria asked him about details, Shershevsky would close his eyes and answer "let me walk around the table and see it...", as if he was switching on a three-dimensional film recorded by a portable camera (which also did not exist then).

Otto Poetzl in his classical experiments on subliminal perception $(24,25)$ proved that the eye sees more and the ear hears better than we can perceive at the conscious level, and thus, subliminal stimuli can inform our judgements, ideas, motivations and decisions. We still know very little about deeper structures of the psyche.

More support to the informational theory of the psyche comes from recent studies of mirror neurons by G. Rizzolatti (26-27). We know situations from everyday life, when two communicating individuals can (especially if they are close and "tuned" to each other) simultaneously remember the same things or express the same ideas. Rizzolatti conducted a set of unique psychophysiological experiments on apes and on humans to experimentally prove the existence of mirror neurons. Rizzolatti is very careful in his formulations and conclusions based on his research. However, he states that mirror neurons influence how we understand intentions of other people, even before they are verbalized (!) and, perhaps, reasons for these intentions as well. This idea can be formulated in a more specific way: actually, these neurons work as informational transmitters and at the same time receivers of non-verbalized information (thoughts), which transform non-material information in something like radio-waves and vice versa, as a kind of biological Bluetooth. Generally speaking, all contemporary IT-systems imitate already existing psychic processes.

I would suggest that the type of mutual understanding related to mirror neurons is the basis of communications between animals. This is the only explanation I have to the phenomena which is so puzzling for everyone watching a video of lions hunting their prey: how 3-4 females can 
work together and decide, who jumps on the prey from the right, who from the left, and who waits in the ambush, and where exactly the ambush should be.

The theory is also supported by clinical observations of patients who were unable to speak their mother tongue but were eager to contact their therapist in a different language, which means that one program of mental functioning was switched off and the other switched on. The first such case, as we know, was described by S. Freud in The Studies of Hysteria in 1895 (28).

\section{IMPLICATIONS FOR PHILOSOPHY, EVOLUTIONARY THEORY AND SOCIAL SCIENCES}

I have already mentioned implications of this theory for psychology, physiology, clinical medicine and psychopharmacology. However, the picture would not be complete without its implications for evolutionary theory, philosophy and social sciences.

It is hardly possible to disagree that Homo Sapience had developed language as a means of interpersonal communication even earlier than the first tools were created. Later, human speech evolved, and mental (verbal) system were developed for storing information and transmitting it to the next generations. Some basic forms of these systems are well known to zoo-psychologists and can be found even in primitive animals (29). Homo Sapience is distinguished by ability to store, generalize, produce and maintain ever growing amounts of information. This vector of civilization is easily traceable in historical anthropology: from primitive forms of communication to human speech; from naming simple objects to abstract concepts and generalizations; from oral to written transmission; from myths to scientific knowledge; from petroglyphs, clay tables and papyrus to contemporary informational systems. Thus, it should be admitted that contemporary notion of evolution - which is still a combination of two biological approaches, classical Darwinism and populational genetics should be reconsidered and should include informational-psychological aspects. Humans did not develop due to their ability to work, as F. Engels suggested in his monography The Part Payed by Labour in the Transition from Ape to Man (30) but rather due to their ability to produce, store, exchange and maintain information and transmit it to the next generations. Information was valued more and more with time, kept secret and protected by extremely expensive protection systems.

Let us turn to humanitarian sciences now. From perspective of the theory suggested above, the main question of philosophy is formulated in its traditional form: the matter is primary, and the subject is primary, and the consciousness is secondary because it can only develop in a society as an informational (ideal, non-material) structure. This structure cannot exist without subjects who carry information, perceive it, store it, accumulate it and transmit it. For more effective achievement of the main evolutionary (!) goal of Homo Sapience (that is, intergenerational transmission of knowledge and experience) these subjects have invented other carries of information, from petroglyphs, papyrus and books to contemporary powerful servers. However, all these information carriers cannot carry or give away any information when there is no subject of its perception.

Let us remember that the term "the main question of philosophy" was introduced by Fredrich Engels in his work Ludwig Feuerbach and the End of Classical German Philosophy in 1886. Some thinkers of the past and the present consider this question unimportant and lacking any epistemic meaning. However, we need to admit that it becomes even more significant in our informational epoch. Moreover, its formulation and solution are crucial for constructing adequate knowledge about the external world. Let us remember that such outstanding scholars of the past as Plato, Leibnitz, Hegel etc. thought that the world of ideas exists 
independently from our consciousness, and the world of things is just an incarnation of the world of ideas.

Contemporary informational technologies require qualitatively new approaches to these problems, as we can see in the everyday life that the world of ideas is by no means independent from our consciousness, just the opposite, it can be formed artificially by qualitative change in established cultural codes. It is also possible to use informational influence for creating trends and vectors of development in the world, be that elevated culture and scientific progress, or inter-ethnic feud and terrorism, or commodity fetishism and sacralization of financial success.

\section{GENIUS IDEAS AND GENIUS MISTAKES}

Let us return to the idea of the brain as a repository of all psychic functions. Descartes, who adhered to Hippocrates's hypothesis, spent a few months dissecting heads of different animals in attempts to study memory, attention etc. $(1,8)$. Of course, he failed this task. However, he is a world-known genius, and there are certain grounds for it. This was the time, when scientists tended to give materialist (mostly, mechanical) explanations to their discoveries and observations. For instance, William Harvey, who discovered the system of blood vessels, compared them to well-known technical devices, pipes and pumps, and stated that human blood system follows the same mechanical principles. Descartes widens this principle and applies the mechanical concept of self-regulation of the organism to interaction of this organism with the external world, thus suggesting the mechanical concept of mental activity.

According to Descartes's concept, the organism interacts with the world via "a nervous machine", centre of which is situated, of course, in the brain. The brain is connected to different organs with "nervous pipes" and "cords", which stretch to open specific "valves" for nervous impulses flowing from the brain (exactly like the blood goes through the blood vessels). Let us repeat it: in Descartes's theory, the body is viewed as a machine functioning in accordance with laws of mechanics, and the brain controls all its movements. However, the human soul still exists in Descartes's system, and it has its own kind of activity, although this aspect of his theory has often been neglected. His main achievement is thought to be the description of the reflex arc, although he did not use the term "reflex" as such.

Before discussing an epic work by I.M. Sechenov Reflexes of the Brain (1863), which introduced the term "reflex" into international science, let us overview the historical period, in which this paper was written. In 1859, Charles Darwin published his unique work On the Origin of Species by Means of Natural Selection, or the Preservation of Favoured Races in the Struggle for Life, which made the majority of scientists in the world reconsider their scientific views. Moreover, it was thought then - although the opinion is to some degree mistaken - that it was impossible to be a scientist and not to be a Darwinist. In the last 160 years, the significance of this monography has not changed, despite the ongoing polemics about Darwinist theory. Some view it as a description of evolution of all living beings in our planet, while others understand it as a description of genetic similarity (or even "the single act of creation") and the most consistent classification of living beings. This unique scientific work became a revolutionary event, which the majority of scientists of the time interpreted as a victory of materialism over idealism. In 1861, extracts from Darwin's book and reviews of it were published in Russia, and their influence on the Russian scientific world was immense. Moreover, Darwin's theory was actively discussed not only by scientists but by all educated people, the Russian intelligentsia.

In this context, an editor of literary anthology Sovremennik (The Contemporary), a famous Russian poet N.A. Nekrasov asked his acquaintance, a young lecturer of the Medical Surgical Academy, a man with European education, I.M. Sechenov to write a review of the most 
important problems in natural sciences for the journal. The result was a treaty rather than a paper; it was called An Attempt to Introduce Physiological Basis into Mental Processes. However, the state censorship and Holy Synod (which at that time was the highest authority in the Orthodox Church) forbade to publish "the dangerous work", which was officially recognized as "an offense to the feelings of believers". Correspondence between the editorial board of the anthology, the censors and Holy Synod is much more extensive than the work itself and is an interesting reading on its own (31). Finally, the paper was published in The Medical Bulletin and had a strictly scientific title The Reflexes of the Brain. This paper, rather interesting but deeply fallacious, was praised as "the beginning of epoch of objective psychology", "an efficient tool for analysing the most complicated mechanisms of the brain", "a sharp weapon of scientific polemics on acute problems of contemporary neurophysiology" etc. I intentionally omit the names of these reviewers, but it is still inappropriate to quote V.I. Lenin without referencing his works, so let me give the exact quote: "He, this scientific psychologist (I.M. Sechenov M.R.), left aside philosophical theories of the soul and began the direct study of the material substrate of psychic phenomena, that is, the nervous processes" (32).

It should be mentioned that the paper, which starts with the phrase: "I suppose that you, my dear reader, must have already participated in discussions about the soul and its relation to the body", - is written with an obvious talent, not as a treaty but rather as an essay, that is, free expression of the author's ideas on the topic. It is noteworthy that in the beginning of the paper, after contrasting himself with various amateurs, the author admits that when a figure of authority expresses his opinion on the topic, it can easily "become a dogma", and the competent author "an idol". This is exactly what happened to his own work and to himself, although historical value of them both should by no means be underestimated.

Sechenov's text is full of statements that are not supported by any evidence, such as "it is generally said...", "thus...", "a reader should not think that...", "in this sense, ...", "anyway..." etc. Let us review the main ideas of this work. "Let us enter, my dear reader, the world of phenomena that are born by activity of the brain. It is generally said that this world embraces mental life as a whole, and there are hardly people in our time who would not accept this idea, to more or less degree, as the truth" (hereinafter the italics is mine - M.R.) (2:32). "For us, physiologists, it is enough that the brain is an organ of the soul, that is, a kind of mechanism, which, when it is set into the motion by whatever reasons, leads to a number of external phenomena typical for mental activity" (2:32). "The reader can instantly understand that all characteristics manifested by activity of the brain, everything that we described by such words as ensoulment, passion, scorn, sadness, joy etc., is nothing else than a result of contraction of a group of muscles - which, as we all know, is a purely mechanical act" (2:33). "Thus, the brain, the organ of the soul, can under certain conditions (according to the concepts of our school) make predetermined movements, like any machine, like hands of the clock moving in a predetermined way because the weights make the wheels inside the clock turn" (2:37). Let us stop here. We will not try to criticize the brilliant author, as it is too easy to criticize a genius of the past from perspective of the present knowledge, but rather reconsider the main achievements of this work.

We should remember that Descartes still considered the soul an independent structure with activity of its own. In Sechenov's concept, however, life of the soul is totally reduced to mechanical hypothesis of inner activity of the brain, excitation and inhibition processes in nervous cells, which Sechenov had studied in his experiments on exiting frog's brain with the crystals of salt. It is admirable that in the end of the paper I.M. Secheniv admits: "Finally, I need to confess that I have constructed all these hypotheses without almost any knowledge of psychological literature" (2:116). 
My outstanding compatriot I.P.Pavlov read Reflexes of the Brain in his early youth, when he studied in seminary in Ryazan, and this work, as he admitted, transformed his life. Based on ideas of I.M. Sechenov, I.P.Pavlov developed a theory of conditional reflexes, concepts of the first and the second signal systems and of higher nervous activity. He did not reconsider I.M. Sechenov's theory but made a number of steps in research of the nervous system, which will be described below.

Let us analyse what was going on after the historical work by I.M. Sechenov was published. In order not to be overwhelmed by the material, we will describe only the most prominent discoveries of physiologists, some of which were awarded by the Nobel Prize.

In 1897, Ch. Sherrington formulated the concept of synapses (while reviewing Descartes's ideas of continuous "nervous pipes"), but he received the Nobel Prize only in 1932, forty years later, for his achievements in studying the structure of the nervous system. In 1904 Ivan Petrovich Pavlov received the Nobel Prize in recognition of his work on the physiology of digestion, through which knowledge on vital aspects of the subject has been transformed and enlarged. In 1906, Camillo Golgi and Santiago Ramón y Cajal received the Nobel Prize for their description of structure and organization of neurons in different areas of the brain. In 1921, Otto Loewi discovered chemical nature of excitation transmitted via synapses and the role of acetylcholine; he received the Nobel Prize in 1936. In 1933, A.V. Kibzakov discovered the role of adrenalin in synaptic transmission. In 1935, V. Erspamer discovered "enteramin", which was later renamed to serotonin, and I. Page and B. Twarog in 1953 discovered serotonin in the brain; serotonin appeared to be neurotransmitter and was informally called "the good mood hormone" or "the happiness hormone".

It is noteworthy that more and more sophisticated methods were used to study the nervous system and the brain, but the role of the brain as a depository of all mental processes has never been questioned. Moreover, the abovementioned substitution of notions, when the nervous was identified with the psychic, has never been noticed at all! Therefore, researchers of psychic and psychopathological phenomena kept using pseudo-physiological terminology, as their attention shifted from excitation and inhibition in the brain and higher nervous activity to pseudo-biochemical interpretation of psychic processes ("chemistry of the psyche"), that is, to the exchange of neurotransmitters in the synaptic cleft.

In 1969, I.P.Lapin and Oxenkrag G. F. (4), making a start from the abovementioned metaphorical name of serotonin ("hormone of happiness"), carefully suggested that development of depression (the most widely spread psychopathology) might be related to the exchange (deficiency) of serotonin in the synaptic cleft. Immediately after this hypothesis was published, it was picked up by leading psychopharmacological companies, urgently proved in theoretical and experimental ways, and on its basis, a new ever-growing group of medicines was developed, which had intriguing fancy name "selective serotonin reuptake inhibitors".

It is strange but nobody has ever noticed that this extremely simplified approach to depressions has a tinge of cynicism and impiety. By prescribing psychopharmacological treatment for 6-8 months, or sometimes for the whole life (similarly to insulin for diabetics), medical doctors have implicitly informed the laymen that his depression was provoked not by loss of his child, or other relative, or financial or social status, or ideals and meaning of his life but resulted from disturbances in exchange of neurotransmitters. In the first part of the paper, I have described in detail how my doubts led me at first to the hypothesis of the biological interface and then to the non-material theory of the psyche. 
In conclusion of this material, we should return to I.P. Pavlov and his idea of the second signal system, which was one of the main prerequisites of non-material theory of the psyche suggested by the author. Let us remember that I.P. Pavlov connected the first signal system, which is based on reflexive activity and mechanisms of the brain (common for humans and animals) with subcortex structures. And the second signal system was interpreted, in Pavlov's terms, as transformation of "signal of signals" (words) in associative fields of the cortex, which I.P. Pavlov described as "the higher nervous activity" (HNA).

In the beginning of his research, I.P. Pavlov adhered to strict physiological position and forbade his co-workers, under the threat of firing them, to psychologize his experiments on conditional reflexes and even to use such expressions as "the dog has realized \wanted $\backslash$ wished". But then the idea of unconditional reflexes was uncritically applied to the psyche as a whole. This change in Pavlov's attitude was clearly defined in his paper presented on the XIV International physiological congress in Rome on September 2, 1932. Let me give two quotes from this paper: "I am convinced that an important stage of human thought, when physiological and psychological, objective and subjective will come together, when a tormenting contradiction between the body and the mind will be resolved in a natural way" (3:491). "This activity of hemispheres and the subcortex, which I described in the most general terms and which supports normal complicated relationships between the organism and the external world, is reasonable to call not mental activity but rather higher nervous activity" (3:482). This is a great mistake of a great scientist: there is no more psyche in a reflex than in a light bulb with a sensor that reacts to any moving object. However, many scientists, who were influenced by I.P.Pavlov and his similarly talented followers, still try to look for material substrate of the psyche or its electric and wave-related equivalents in the cortex and hemispheres. Alas, the psyche cannot be found there, it is non-material.

Theory of I.P. Pavlov, which reflected the state of science of his time, has significantly influenced development of physiology, clinical psychiatry and academic psychology. In works of my reputable contemporaries, there are still quotes like the abovementioned and phrases like the following, which I quote here without mentioning the name of its author (who is a prominent and well-known specialist): "The brain can not only respond adequately to stimuli but also foresee the future, actively plan behaviour and implement these plans". But the brain is just a tissue, and it cannot foresee anything!

Let us stress it once again that I.P. Pavlov, although his theories should be critically reviewed, is an outstanding physiologist and one of geniuses of the XX century. As to his investment into clinical medicine and psychology, importance of which has been repeatedly stressed by his students and followers, let us see how he assessed implications of his theory for adjoining fields of knowledge and practice. In the end of his life, he stated it in rather modestly: "I am not a clinician, I have always been a physiologist, and it is too late now: I cannot become a clinician" - and he continues, that is why "in my current reflections, as well as in my former excurses in neuropathology and psychiatry, I do not dare to claim, when discussing such material, that I am competent from clinical perspective" (3:515). There is one more quote from Collected Works by I.P. Pavlov: “... I would like to warn against misunderstanding in relation to me. I do not deny psychology as understanding of individual's inner world" (3:104). I hope that our colleagues understand the difference between the idea of individual's inner world and the physiology of higher nervous activity.

Let us repeat it once again that mistakes of great scientists are great mistakes, and they need to be thoroughly studied and analysed. I.P. Pavlov cannot be blamed though: he anticipated in a brilliant way that there is a difference between nervous regulation of somatic functions and 
psychic activity, and he tried to explain the latter in terms of science of his time by formulating hypothesis of the HNA. Theory of information was developed in the end of 1940-s, and I.P. Pavlov, whose $170^{\text {th }}$ anniversary will be celebrated by scientists all over the world in 2019, died in 1936. If theory of information had appeared earlier, I.P. Pavlov could have made completely different conclusions about the second signal system.

\section{AFTERWORD}

Some colleagues, who read this material, assessed the non-material theory of the psyche as a discovery which will qualitatively change all our approaches to the psyche and psychopathology, and I am grateful to them for their appreciation. Others reacted with cognitive dissonance and promised to think it over but sounded rather sceptical; these ideas contradicted everything that they learnt, believed and used as basis for their scientific generalizations, experimental and therapeutic approaches and strategies. The third group of specialists refused to listen and to discuss this theory at all because "it contradicts the established views and authoritative opinions". It is surprising that young people in the audience, undergraduate and postgraduate students, react to this theory with asking "Oh, is it possible that someone holds a different view?" I am sure that adequate understanding of the new theory is a matter of time, although everyone can agree that however hard you try to dissemble the radio, you will never find the music in it!

It has been proved that:

\section{CONCLUSIONS}

1) for two thousand years, scientists have not noticed the following substitution of notions: they were speaking about studying and treating the psyche while in reality they were studying the brain and treating it by means of lobotomy, the ECT and psychopharmacology, at the same time elaborating pseudo-physiological terminology to describe the brain-driven mechanisms of mental processes;

2) the brain and the psyche are two interrelated but principally different systems;

3) the brain and the nervous system are material, they regulate activity of inner organs, reflexive reactions and adaptive functions of the organism; at the same time, the brain is the biological interface, which maintains a connection between the real and the ideal;

4) the psyche is a non-material informational structure that develops in result of language programming of the brain in a social informational environment; it is the highest regulator of cognitive, emotional, behavioural and ideomotor acts, that is, of social adjustment of personality in general, in accordance with requirements for language and culture in a specific society, which influence the development of the psyche;

5) neuroses and other mental disorders resulting from individually important psychic traumata or "blows of the fate" (that is, more than $50 \%$ of contemporary psychopathology), when information (psychic trauma) damages the functioning of an informational system (the psyche), are not related to pathology of the brain;

6) such mental disorders require qualitatively new clinical approaches and qualitatively different paradigm of therapy and rehabilitation targeting the psyche not the brain;

7) contemporary academic science has not studied the psyche as an informational (ideal, non-material) structure yet, and such an approach would require changing paradigm of all human sciences. 


\section{References}

Descartes R. Sobranie sichineniy (Collected works). 2 volumes. Russian translation. Volume 1. - Moscow: Misl, 1989:654.

Sechenov I.M. Refleksi golovnogo mozga (Reflexes of the brain). - Moscow: Ministry of education of the USSR, 1953:31, 32, 33, 36, 37, 117.

Pavlov I.P. Sobranie sichineniy (Collected works). Volumes 1-5. - Moscow-Leningrad: Academy of sciences of the USSR, Volume. III, part 1, 1949:104, 323-340, 349.

Lapin I. P., Oxenkrag G. F. Intensification of the central serotoninergic processes as a possible determinant of thymoleptic effect. — Lancet, N 1, 1969:132-136.

Freud S. Avtoportret (The self-portrait). Russian translation - St. Petersburg: The East European Psychoanalytic Institute, 2006:256.

Bechterev V.M. Budustchee psihiatrii: vvedenie v patologicheskuyu refleksologiyu (The Future of psychiatry: Introduction into pathological reflexology). - St. Petersburg: Nauka, 1997:23.

Dubrovsky D. I. Problema soznaniya I mozga: teoreticheskoe reshenie (The problem of the consciousness and the brain: a theoretical solution). - Moscow: Kanon+, ROOI Rehabilitation, 2015:208.

Reshetnikov M.M. Psihicheskoe rasstroystvo (Mental disorder). - St. Petersburg: The East European Psychoanalytic Institute, 2008:272.

Reshetnikov M.M. Kriticheskij postmaterialism v psihologii i psihiatrii (Critical postmaterialism in psychology and psychiatry) // Neurological Bulletin, Volume XLIII, issue 2, 2011:66-69.

Lacan J. Funkcia i pole rechi i yazika v psihoanalize (Function and field of the speech and the language in psychoanalysis). The presentation at the Congress in Rome, the Institute of Psychology at the University of Rome on September 26 and 27, 1953. Russian translation. - Moscow: Gnosis, 1995:5-15.

Reshetnikov M.M. Nematerialnaya teoriya psihiki (The non-material theory of the psyche). Journal Forum of young scientists, № 6 (22), 2018: 1-7.

Reshetnikov M.M. What is the Psyche? What are we Curing? Journ. Anthropology. Vol. 6, Issue 3, 2017:11-15.

Reshetnikov M.M. Problem of Relation between Brain and Mind in Physiology, Medicine and Psychology. Journ. of Psychiatry and Psychiatric Disorders. Issue 1(6), 2017:313-316.

Reshetnikov M.M. During Two Thousand Years We Were Looking for the Psyche in a Wrong Place (Ideas Live Their Own Life). - International Journal of Current Innovations in Advanced Research, Volume 1, Issue 4, August2018:82-87.

Reshetnikov M.M. Non-Material Theory of the Psyche: Historical Prerequisites, Argumentation and Practical Implications // International Journ. Psychology \& Psychological Research, Volume 3 Issue 5, 2018:1-7.

Reshetnikov M.M. Non-material Nature of the Psyche // Psychological Review. Issue 6(2), Vol. 125. American Psychological Association, 2018:1035-1047.

Wiener N. Kibernetika ili upravlenie b svyaz v dzivitnih i mashine (Cybernetics, or control and communication in the animal and the machine). Russian translation - Moscow: Sovetskoe radio, 1968:325.

Gubachev J.M., Stabrovsky E.M. Klinicheskie I fiziologicheskie osnovi psihosomaticheskih sootnosheniy (Clinical and physiological basis of psychosomatic relationship). - Leningrad: Medicine, 1981:176.

Laborit H. Metabolicheskie I psihofarmakologicheskie osnovi neyro-fiziologii (Metabolic and pharmacological basis of neuro-physiology) / Russian translation. - Moscow: Medicine, 1974:168.

Lubovsky V.I. Razvitie slovesnoy regulatsii u detey - v norme i patologii (Development of verbal regulation of activity in children, normal and pathological). — Moscow: Pedagogics, 1978:224.

Petrovsky V.A. Psihologiya neadaptivnoy activnosti (Psychology of non-adaptive activity). - Moscow, $1992: 45$.

Bartra R. Society's Fascination with the Wild Outsider. The Artificial Savage: Modern Myths of the Wild Man. Michigan, 1997:13-37.

Luria A.R. Malenkaya kniga o bolshoy pamyati (Small book of the large memory). - Moscow, 1968:88.

Godfrua J. Chto takoe psihologiya (What is psychology). 2 volumes. Russian translation. The $2^{\text {nd }}$ edition. Volume1. Moscow: Mir, 1996:496.

Grimak L.P. Rezervi chelovecheskoy psihiki (Reserves of the human psyche). - Moscow: Lenand, 1989:238. 
Rizzolatti, G., Fadiga, L., Gallese, V. and Fogassi, L. "Premotor cortex and the recognition of motor actions" // Cognitive Brain Research, No. 3, 1996:131-141.

Rizzolatti G., Fogassi L., Gallese V.: Mirrors in the Mind. Scientific American Band 295, Nr. 5, November 2006:3037.

Freud S. Issledovaniya isterii (The studies of hysteria). Russian translation. - St. Petersburg: The East European Psychoanalytic Institute, 2005:454.

Gardner R.A., Gardner B.T. Comparative psychology and language acquisition. In T.A. Sebok and J.-U.Sebok (eds.): Speaking of Apes: A Critical Anthology of Two-Way Communication with Man. New York: Plenum Press, 1980:287-329.

Engels $F$. Rol truda v processe prevrasheniya obezyani v cheloverka (The Part Payed by Labour in the Transition from Ape to Man) // Marx, K. Engels F. Collected works. Russian translation. Volume 20. - Moscow: Politizdat, 1961:827.

Terekhov P.G. I.M.Sechenov I materialisticheskaya psihologiya (Sechenov I.M. and materialist psychology). Moscow: Academy of sciences of the USSR, 1957:55-109.

Lenin V.I. Sobranie sichineniy (Collected works). The $4^{\text {th }}$ edition, Volume 1 - Moscow: The state edition of the political literature, 1941-1967:127. 